\title{
Unsur Menyalahgunakan Kewenangan dalam Tindak Pidana Korupsi sebagai Kompetensi Absolut Peradilan Administrasi
}

\author{
Mohammad Sahlan \\ Biro Hukum dan Organisasi, Kementerian Kelautan dan Perikanan \\ Gedung Mina Bahari IV Lt. 3B \\ Jl. Medan Merdeka Timur No. 16 Jakarta Pusat 10110, \\ con9.sahlan@gmail.com / cong.sahlan@kkp.go.id
}

\begin{abstract}
The main issue in this research is whether the power abuse in Corruption is still an absolute competence of Corruption Justice or is shifted into the administrative justice in post-regulation of Government Administration Act. This is a research on normative law that is analytical prescriptive through conceptual approach, statute approach, and case approach. The results of the research showed that the concept of the power abuse in the Government Administration Act theoretically and practically is equal with the concept of power abuse in Corruption Eradication Law. Therefore, those two justices attributively have the absolute competence to examine and determine the elements of power abuse in corruption. However, based on the principle of "lex posteriori derogate legi priori", the authority to examine and determine the element of power abuse in corruption comes to be the absolute competence of Justice Administrative.
\end{abstract}

Keywords: Authority, justice, power abuse

\begin{abstract}
Abstrak
Inti permasalahan dalam penelitian ini apakah pasca diundangkannya UU Administrasi Pemerintahan, unsur "menyalahgunakan kewenangan" dalam Tipikor masih merupakan kompetensi absolut Peradilan Tipikor atau beralih ke Peradilan Administrasi. Penelitian ini merupakan penelitian hukum normatif yang bersifat preskriptif analitis, melalui conceptual approach, statute approach, dan case approach. Hasil penelitian menyimpulkan, secara teoritis dan praktis konsep "penyalahgunaan wewenang" dalam UU Administrasi Pemerintahan sama dengan konsep "menyalahgunakan kewenangan" dalam UU Pemberantasan Tipikor. Oleh karena itu, kedua peradilan tersebut secara atributif sama-sama memiliki kompetensi absolut untuk memeriksa dan memutus unsur menyalahgunakan kewenangan dalam Tipikor. Namun demikian, berdasarkan asas "lex posteriori derogate legi priori", kewenangan untuk memeriksa dan memutus unsur "menyalahgunakan kewenangan" dalam Tipikor menjadi kompetensi absolut Peradilan Administrasi.
\end{abstract}

Kata Kunci: Kewenangan, peradilan, penyalahgunaan wewenang. 


\section{Pendahuluan}

Penelitian ini berangkat dari adanya conflict norm pasca diundangkannya Undang-Undang Nomor 30 Tahun 2014 tentang Administrasi Pemerintahan (UU Administrasi Pemerintahan), yaitu Pasal 17 sampai dengan Pasal 21 yang mengatur tentang larangan penyalahgunaan wewenang oleh Badan dan/atau Pejabat Pemerintahan serta pemberian kewenangan kepada Aparat Pengawasan Intern Pemerintah (APIP) dan Peradilan TUN (Peradilan Administrasi) untuk melakukan pengawasan dan pengujian mengenai ada atau tidak ada unsur penyalahgunaan Wewenang yang dilakukan oleh Pejabat Pemerintahan. ${ }^{1}$ Sementara, sebelumnya telah ada ketentuan Pasal 3 UU Nomor 31 Tahun 1999 tentang Pemberantasan Tindak Pidana Korupsi, sebagaimana telah diubah dengan UU Nomor 20 Tahun 2001 (UU Pemberantasan Tipikor)² jo. Pasal 5 dan Pasal 6 UU Nomor 46 Tahun 2009 tentang Pengadilan Tindak Pidana Korupsi (UU Pengadilan Tipikor), ${ }^{3}$ yang salah satu unsurnya mengatur Tipikor karena menyalahgunakan kewenangan, dimana kompetensi absolut untuk memeriksa masalah tersebut diberikan kepada Pengadilan Tipikor.

Ketentuan dalam UU Administrasi Pemerintahan tersebut telah menimbulkan pro kontra diantara para ahli hukum, khususnya ahli Hukum Pidana dan ahli Hukum Administrasi Negara berkenaan dengan keberlakuan ketentuan dimaksud dan pengaruhnya terhadap kewenangan Peradilan Tipikor. Guntur Hamzah, ${ }^{4}$ Guru Besar Hukum Administrasi Universitas Hasanuddin, menyatakan keberadaan UU Administrasi Pemerintahan akan memperkuat dan menambah daya dobrak upaya pemberantasan korupsi karena dengan adanya APIP, adanya dugaan penyalahgunaan wewenang dapat dideteksi sejak dini sebagai upaya preventif (pencegahan).

${ }^{1}$ UU Administrasi Pemerintahan diundangkan tanggal 17 Oktober 2014 (LNRI Tahun 2014 Nomor 292, TLNRI Nomor 5601).

${ }^{2}$ UU Pemberantasan Tipikor diundangkan tanggal 16 Agustus 1999 (LNRI Tahun 1999 Nomor 140, TLNRI Nomor 3874). Sedangkan UU Nomor 20 Tahun 2001 diundangkan tanggal 21 Nopember 2001 (LNRI Tahun 2001 Nomor 134, TLNRI Nomor 4150).

${ }^{3}$ UU Pengadilan Tipikor diundangkan tanggal 29 Oktober 2009 (LNRI Tahun 2009 Nomor 155, TLNRI Nomor 5074).

${ }^{4}$ Lihat http://www.hukumonline.com/berita/baca/lt5514fdcf7f $91 \mathrm{~b} /$ uu-administrasi-pemerintahan-triggerberantas-korupsi, diakses tanggal 28 Februari 2016. 
Namun pendapat berbeda disampaikan oleh Krisna Harahap, Hakim Agung pada Mahkamah Agung yang secara tegas menyatakan UU Administrasi Pemerintahan menghambat upaya pemberantasan Tipikor karena ketentuanketentuan yang tertuang dalam UU Administrasi Pemerintahan nyata-nyata tidak selaras dengan UU Pemberantasan Tipikor, khususnya Pasal $3 .{ }^{5}$ Lebih parah lagi, ketentuan dalam UU Administrasi Pemerintahan tersebut bahkan bisa mereduksi kewenangan Peradilan Tipikor dalam menilai unsur "menyalahgunakan kewenangan" dalam Tipikor. Hal ini nampak dari kebijakan Presiden Jokowi yang menginstruksikan kepada Jaksa Agung dan Kapolri agar mendahulukan proses administrasi pemerintahan sesuai ketentuan UU Administrasi Pemerintahan sebelum melakukan penyidikan atas laporan masyarakat berkenaan dengan dugaan penyalahgunaan wewenang, khususnya dalam pelaksanaan Proyek Strategis Nasional. ${ }^{6}$

Permasalahan timbul karena konsep "penyalahgunaan wewenang" dalam UU Administrasi Pemerintahan oleh beberapa ahli hukum dipandang sama dengan konsep "menyalahgunakan kewenangan" karena jabatan dalam UU Pemberantasan Tipikor. Ketentuan tersebut berpotensi menimbulkan sengketa kewenangan absolut antara Peradilan Tipikor dan Peradilan Administrasi. Untuk itu, unsur menyalahgunakan kewenangan dalam Tipikor sebagai kompetensi absolut Peradilan Administrasi menarik untuk dikaji.

\section{Rumusan Masalah}

Berdasarkan uraian di atas, permasalahan yang diangkat dalam penelitian ini ialah apakah unsur "menyalahgunakan kewenangan" dalam Tipikor merupakan kompetensi absolut Peradilan Tipikor atau kompetensi absolut Peradilan Administrasi?

5 Lihat http://news.detik.com/berita/2873765/uu-administrasi-pemerintahan-dinilai-mengudeta-pemberantasan-korupsi, diakses tanggal 28 Februari 2016.

${ }^{6}$ Lihat Bagian Keenam angka 1 Instruksi Presiden RI Nomor 1 Tahun 2016 tentang Percepatan Pelaksanaan Proyek Strategis Nasional. 


\section{Tujuan Penelitian}

Penelitian ini bertujuan untuk mengkaji dan menganalisis siapa yang berwenang untuk untuk memeriksa, mengadili, dan memutus unsur menyalahgunakan kewenangan dalam Tipikor antara Peradilan Tipikor dan Peradilan Administrasi pasca diundangkannya UU Administrasi Pemerintahan.

\section{Metode Penelitian}

Kajian ini merupakan kajian hukum normatif yang bersifat preskriptif analitis, melalui conceptual approach, statute approach, dan case approach. Untuk menentukan siapa yang berwenang untuk memeriksa dan memutus unsur menyalahgunakan kewenangan dalam Tipikor, maka terlebih dahulu perlu ada kejelasan konsep mengenai istilah "penyalahgunaan wewenang" sebagai terminologi yang digunakan dalam UU Administrasi Pemerintahan dan istilah "menyalahgunakan kewenangan" sebagai terminologi yang digunakan dalam UU Pemberantasan Tipikor. Perlu dikaji apakah istilah "penyalahgunaan wewenang" merupakan konsep yang sama dengan istilah "menyalahgunakan kewenangan" atau sebaliknya. Conceptual approach digunakan untuk membandingkan dan menganalisis konsep penyalahgunaan wewenang dan konsep menyalahgunakan kewenangan yang disampaikan oleh para ahli bahasa dan para sarjana hukum. Statute approach diperlukan untuk mengkaji pengaturan masalah penyalahgunaan wewenang dan menyalahgunakan kewenangan dalam hukum positif Indonesia. Kemudian case approach untuk melihat penggunaan istilah penyalahgunaan wewenang dan menyalahgunakan kewenangan dalam praktek penegakan hukum di Indonesia, khususnya penegakan hukum pidana. Sumber data dalam penelitian ini terdiri dari data sekunder, yang berupa bahan hukum primer, sekunder, dan tersier. Data yang terkumpul dianalisis secara deskriptif kualitatif. 


\section{Hasil Penelitian dan Pembahasan}

\section{Konsep Penyalahgunaan Wewenang dan Konsep Menyalahgunakan Kewenangan}

"Penyalahgunaan wewenang" dan "menyalahgunakan kewenangan" merupakan istilah yang lahir dari doktrin Hukum Administrasi Negara dan lazim digunakan dalam ranah hukum tersebut. Secara etimologis, istilah "penyalahgunaan" dan "menyalahgunakan" berasal dari dua suku kata "salah-guna". Penyalahgunaan yang berbentuk noun berarti proses, cara, perbuatan menyalahgunakan; penyelewengan, sedangkan "menyalahgunakan" yang berbentuk verb dimaknai melakukan sesuatu tidak sebagaimana mestinya; menyelewengkan. ${ }^{7}$ Istilah penyalahgunaan/menyalahgunakan dalam istilah Belanda dikenal dengan misbruik yang memiliki kemiripan dengan istilah missbrauch dalam bahasa Jerman atau misuse dan abuse dalam istilah bahasa Inggris yang maknanya selalu diasosiasikan dengan hal yang bersifat negatif yaitu penyelewenangan. ${ }^{8}$ Jadi antara istilah "penyalahgunaan" dan "menyalahgunakan" tidak ada perbedaan, "penyalahgunaan" menunjuk pada proses, cara, perbuatannya, sedangkan "menyalahgunakan" menunjuk pada tindakan atau pelaksanaanya.

Sementara itu, istilah "wewenang" dan "kewenangan" berasal dari kata "wenang" keduanya berbentuk noun. ${ }^{9}$ Wewenang dimaknai Hak dan kekuasaan untuk bertindak; kewenangan. Sedangkan kewenangan berarti 1. Hal berwenang; 2. Hak dan kekuasaan yang dipunyai untuk melakukan sesuatu. Yang dalam istilah bahasa Inggris dikenal dengan "authority" dan tidak ada pembedaan antara keduanya, sama halnya dengan istilah dalam bahasa Belanda, yang tidak membedakan keduanya. Istilah yang sering digunakan adalah bevoegdheid, meskipun ada istilah lain yang terjemahannya adalah kewenangan atau kompetensi yaitu bekwaamheid.10 Jadi secara terminologis, antara istilah

7 Badan Pengembangan dan Pembinaan Bahasa Kementerian Pendidikan dan Kebudayaan (BP2B, Kemendikbud), Kamus Besar Bahasa Indonesia (KKBI), Kamus Versi Online/Daring (Dalam Jaringan), kbbi.web.id/ salab\%20guna.menyalahgunakan, diunduh pada hari Rabu, 8 Maret 2016.

${ }^{8}$ Budi Parmono, Penyalahgunaan Wewenang Dalam Tindak Pidana Korupsi di Indonesia: Disertasi, Fakultas Hukum UB, Malang, 2011, hlm. 137. Lihat juga Victoria Bull, Oxford Learner's Pocket Dictionary: Fourth Edition, Oxford University Press, Oxford, 2012, hlm. 2 dan 282.

${ }^{9}$ BP2B, Kemendikbud, KKBI, Daring, kbbi.web.id/wenang, diunduh pada hari Minggu, 6 Desember 2015.

${ }^{10}$ Susi Moeimam dan Hein Steinhauer, Kamus Belanda-Indonesia, Gramedia Pustaka, Jakarta, 2005, hlm. 100. 
"wewenang" dengan "kewenangan" tidak ada perbedaan substansial/prinsipil.11 Istilah wewenang dan kewenangan selalu di kaitkan dengan "hak dan kekuasaan untuk bertindak atau melakukan sesuatu". Jadi pembedaan yang dilakukan terhadap konsepsi "menyalahgunakan kewenangan" dan "penyalahgunaan wewenang" dengan argumentasi adanya perbedaan pengertian atau definisi yuridis antara "kewenangan" dan "wewenang" menjadi tidak lagi relevan. ${ }^{12}$

\section{Konsep Penyalahgunaan Wewenang}

Penyalahgunaan wewenang dalam konsep Hukum Administrasi Negara selalu diparalelkan dengan konsep detournament de pouvoir dalam sistem hukum Prancis atau abuse of power/misuse of power dalam istilah bahasa Inggris. ${ }^{13}$ Secara historis, konsep "detournament de pouvoir" pertama kali muncul di Prancis dan merupakan dasar pengujian lembaga Peradilan Administrasi Negara terhadap tindakan pemerintahan dan dianggap sebagai asas hukum yang merupakan bagian dari "de principes generaux $d u$ droit". Conseil d'Etat adalah lembaga peradilan pertama yang menggunakannya sebagai alat uji, yang kemudian diikuti oleh negara-negara lain. Pejabat pemerintahan dinyatakan melanggar prinsip détournement de pouvoir, manakala tujuan dari keputusan yang dikeluarkan atau tindakan yang dilakukan bukan untuk kepentingan atau ketertiban umum tetapi untuk kepentingan pribadi si pejabat (termasuk keluarga atau rekannya). ${ }^{14}$

Konsep "détournement de pouvoir" oleh Conseil d'Etat Prancis telah dikembangkan menjadi tiga kategori, ${ }^{15}$ yaitu: a. when the administrative act is completely taken without the public interest in mind; $b$. when the administrative act is

11 Pimpinan Pusat Ikatan Hakim Indonesia (PP IKAHI), Undang-Undang Administrasi Pemerintaban Dalam Upaya Pemberantasan Korupsi, Sinar Grafika, Jakarta Timur, 2016, hlm. 93.

12 Lihat D. Andhi Nirwanto, "Arah Pemberantasan Korupsi Ke Depan (Pasca Undang-Undang Administrasi Pemerintahan)", Makalah, disampaikan dalam Seminar Nasional dalam rangka H.U.T. IKAHI Ke-62 dengan tema "Undang-Undang Administrasi Pemerintahan, Menguatkan atau Melemahkan Upaya Pemberantasan Korupsi", Hotel Mercure, Jakarta, tanggal 26 Maret 2015, hlm. 16-19.

13 Philiphus M. Hadjon, dkk., Hukum Administrasi dan Tindak Pidana Korupsi: Cetakan Kedua, Gajahmada University Press, Yogyakarta, 2012, hlm. 21-22.

14 Yulius, "Perkembangan Pemikiran dan Pengaturan Penyalahgunaan Wewenang di Indonesia (Tinjauan Singkat Dari Perspektif Hukum Administrasi Negara Pasca Berlakunya Undang-Undang Nomor 30 Tahun 2014)”, artikel dalam Jurnal Hukum dan Peradilan, Badan Penelitian dan Pengembangan Hukum dan Peradilan Mahkamah Agung RI, Volume 04 Nomor 3 November 2015, hlm. 364.

15 Yulius, "Perkembangan Pemikiran ..., Ibid.., hlm. 365. Lihat juga Putusan MARI Nomor 977K/PID/2004, tanggal 10 Juni 2005, hlm. 196-197. Lihat juga Putusan MARI Nomor 979K/PID/2004, tanggal 10 Juni 2005, hlm. 86-88. 
taken on the basis of the public interest but the discretion which the administration exercises in doing so was not conferred by law for that purpose; c. in cases of détournement de procedure where the administration, concealing the real content of the act under a false appearance, follows a procedure reserved by law for other purposes.

Konsep "détournement de pouvoir" yang lahir dan berkembang di Prancis ini kemudian membawa pengaruh pada penegakan hukum di Negara lain seperti di Belanda sebagai salah satu Negara jajahan Prancis dan Indonesia sebagai Negara jajahan Belanda. Penyalahgunaan wewenang oleh Hoge Raad dijadikan sebagai dasar pertimbangan hukum dalam membuat Putusan. Sementara di Indonesia, penyalahgunaan wewenang dijadikan alasan (dasar) gugatan bagi seseorang atau badan hukum perdata yang merasa kepentingannya dirugikan oleh suatu Keputusan TUN (pihak Penggugat). ${ }^{16}$

Verklarend Woordenboek Openbaar Bestuur merumuskan "penyalahgunaan wewenang" sebagai penggunaan wewenang tidak sebagaimana mestinya. Dalam hal ini, pejabat dianggap melanggar asas spesialitas (asas tujuan) karena yang bersangkutan menggunakan wewenangnya untuk tujuan yang menyimpang dari tujuan yang telah diberikan kepada wewenang tersebut. ${ }^{17}$

Asas spesialitas ini dahulu pernah diterapkan dalam hukum positif Indonesia, yaitu dalam Pasal 53 ayat (2) huruf b UU Nomor 5 Tahun 1986 tentang Peradilan Administrasi, berkenaan dengan alasan-alasan untuk mengajukan gugatan ke Peradilan Administrasi. Pada bagian penjelasannya, ketentuan ini dinyatakan secara tegas sebagai "penyalahgunaan wewenang", walaupun kemudian ketentuan ini dihapus dan diganti dengan AUPB pada saat dilakukan perubahan terhadap undang-undang dimaksud. ${ }^{18}$ Ketentuan ini dalam praktek hukum pidana, khususnya pada Peradilan Tipikor seringkali digunakan untuk

16 Lihat Pasal 53 ayat (2) huruf b UU Nomor 5 Tahun 1986 tentang Peradilan TUN. Lihat juga Yulius, "Perkembangan Pemikiran ..., Ibid.

17 Philipus M. Hadjon, dkk., Hukum Administrasi dan..., Op.Cit., hlm. 21-22. Lihat juga Arfan Faiz Muhlizi, "Reformulasi Diskresi Dalam Penataan Hukum Administrasi", Artikel dalam Jurnal RechtsVinding, Volume 1 Nomor 1 Januari-April 2012., hlm. 94.

18 Istilah "penyalahgunaan wewenang" dalam UU Peradilan TUN setelah perubahan tidak lagi dikenal, bahkan tidak termasuk dalam AUPB. Istilah tersebut baru muncul kembali pada saat UU Administrasi Pemerintahan diundangkan sebagai salah satu AUPB, namun dengan istilah berbeda yaitu "tidak menyalahgunakan kewenangan" dengan makna diperluas. Lihat Tri Cahya Indra Permana, Hak Permohonan Pejabat/Badan Atas Dugaan Penyalahgunaan Wewenang: Bunga Rampai Peradilan Administrasi Kontemporer, Editor Subur, dkk., Genta Press, Yogyakarta, 2014, hlm. 51-52. 
menjelaskan unsur "menyalahgunakan kewenangan" yang terdapat dalam ketentuan Pasal 3 UU Pemberantasan Tipikor melalui penafsiran ekstensif dengan pendekatan doktrin otonomi hukum pidana. ${ }^{19}$

Terjadinya penyalahgunaan wewenang perlu diukur dengan membuktikan secara faktual bahwa seorang pejabat telah menggunakan wewenangnya untuk tujuan lain atau tidak. Harus dapat dibuktikan juga bahwa terjadinya penyalahgunaan wewenang dilakukan secara sadar dengan mengalihkan tujuan yang telah diberikan kepada wewenang itu (bukan karena kealpaan). Pengalihan tujuan tersebut didasarkan atas interest pribadi, baik untuk kepentingan dirinya sendiri ataupun untuk orang lain. ${ }^{20}$

Secara yuridis, penyalahgunaan wewenang dalam UU Administrasi Pemerintahan dinyatakan terjadi ketika "badan dan/atau pejabat pemerintahan dalam membuat keputusan dan/atau melakukan tindakan melampaui wewenang, mencampuradukkan wewenang, dan/atau bertindak sewenang-wenang." 21 Badan dan/atau Pejabat Pemerintahan melampaui wewenang ketika keputusan dan/atau tindakan yang dilakukan dengan a). melampaui masa jabatan atau batas waktu berlakunya wewenang; b). melampaui batas wilayah berlakunya wewenang; dan/atau c). bertentangan dengan ketentuan peraturan perundangundangan." 22 Sedangkan keputusan dan/atau tindakan Badan dan/atau Pejabat Pemerintahan dikategorikan mencampuradukkan wewenang apabila dilakukan di luar cakupan bidang atau materi wewenang yang diberikan dan/atau bertentangan dengan tujuan wewenang yang diberikan."23 Terakhir Badan dan/atau Pejabat Pemerintahan dinyatakan sewenang-wenang manakala keputusan dan/atau tindakannya dilakukan tanpa dasar kewenangan dan/atau bertentangan dengan Putusan Pengadilan yang berkekuatan hukum tetap."24

${ }^{19}$ Lihat Putusan Mahkamah Agung Republik Indonesia (MARI) Nomor: 14/Pid.Sus /2012/PN.AB. dengan Terdakwa Edi Tri Sukmono, SH. Alias Edi dan Putusan MARI Nomor: 03/PID.SUS/TPK/2013/PN.PBR. dengan Terdakwa Amril Daud.

20 Philipus M. Hadjon, dkk., Hukum Administrasi dan..., Op.Cit., hlm. 22. Lihat juga Abdul Latif, Hukum Administrasi Dalam Tindak Pidana Korupsi, Prenada Media Group, Jakarta, 2014, hlm. 35.

${ }^{21}$ Lihat ketentuan Pasal 17 UU Administrasi Pemerintahan.

${ }^{22}$ Lihat ketentuan Pasal 18 ayat (1) UU Administrasi Pemerintahan.

${ }^{23}$ Lihat ketentuan Pasal 18 ayat (2) UU Administrasi Pemerintahan.

${ }^{24}$ Lihat ketentuan Pasal 18 ayat (3) UU Administrasi Pemerintahan. 
UU Administrasi Pemerintahan tidak menjelaskan definisi, pengertian, maupun konsep penyalahgunaan wewenang. Pasal 17 UU Administrasi Pemerintahan hanya mengatur tentang larangan penyalahgunaan wewenang dan tiga spesies larangan penyalahgunaan wewenang, yang meliputi larangan melampaui wewenang, larangan mencampuradukkan wewenang dan larangan bertindak sewenang-wenang, yang secara konseptual dan teoritis menurut ahli Hukum Administrasi Negara dan praktisi Hukum Administrasi Negara (hakim PTUN) tidak tepat dan cenderung menyesatkan. ${ }^{25}$ Namun demikian, perluasan makna penyalahgunaan wewenang dalam UU Administrasi Pemerintahan dan perdebatan yang menyertainya tidak boleh menghalangi keberlakuan norma penyalahgunaan wewenang dalam undang-undang dimaksud, karena sebagai undang-undang yang dibentuk oleh lembaga yang berwenang yaitu legislatif, maka sesuai dengan asas legalitas undang-undang tersebut mengikat secara umum dan harus dilaksanakan serta tidak dapat disimpangi sebelum di cabut atau dibatalkan oleh lembaga Negara yang berwenang. ${ }^{26}$

\section{Konsep Menyalahgunakan Kewenangan}

Istilah "menyalahgunakan kewenangan" merupakan istilah yang digunakan dan populer dalam hukum pidana, khususnya dalam praktek peradilan pidana ketika berbicara tentang Tipikor yang berkaitan dengan jabatan publik atau jabatan pemerintahan. Hal ini tidak mengherankan karena "menyalahgunakan kewenangan" merupakan salah satu unsur penting dalam Tipikor yang berkaitan dengan jabatan bahkan merupakan bestanddeel delict.27 Menyalahgunakan kewenangan sebagai salah satu unsur dalam Tipikor menurut Abdul Latif,28

${ }^{25}$ Lihat Tri Cahya Indra Permana, Hak Permohonan ..., Op. Cit., hlm. 53. Lihat juga Philipus M. Hadjon, "Peradilan Tata Usaha Negara Dalam Konteks Undang-Undang No. 30 Th. 2014 tentang Administrasi Pemerintahan", Artikel dalam Jurnal Hukum dan Peradilan, Badan Penelitian dan Pengembangan Hukum dan Peradilan Mahkamah Agung RI, Volume 04 Nomor 1 Maret 2015, hlm. 58-60. Lihat juga Philipus M. Hadjon, "Peradilan Tata Usaha Negara Dalam Konteks Undang-Undang Nomer 30 Th. 2014", Makalah, disampaikan dalam Colloqium Membedah Undang-Undang Nomor 30 Tahun 2014 tentang Administrasi Pemerintahan, 5 Juni 2015, Garden Palace Surabaya., hlm. 11..

26 Yulius, "Perkembangan Pemikiran ..., Ibid., hlm. 377.

${ }^{27}$ Lihat ketentuan Pasal 3 UU Pemberantasan Tipikor. Menurut yurisprudensi Mahkamah Agung RI, unsur "menyalahgunakan kewenangan" dalam ketentuan Pasal 3 UU Pemberantasan Tipikor merupakan inti delik dari pasal tersebut, sehingga dalam penerapannya untuk melakukan pemidanaan terhadap terdakwa korupsi berdasarkan ketentuan Pasal 3 ini, unsur "menyalahgunakan kewenangan" harus terpenuhi. Lihat Putusan Mahkamah Agung RI Nomor 1485K/Pid.Sus/2013, tanggal 2 Oktober 2013, hlm. 132.

28 Abdul Latif, Hukum Administrasi Dalam..., Op. Cit., hlm. 41. 
merupakan species delict dari unsur melawan hukum sebagai genus delict. Menyalahgunakan kewenangan dalam konteks ini akan selalu berkaitan dengan jabatan pejabat publik, bukan dalam kaitan dan pemahaman jabatan dalam ranah struktur keperdataan. Namun demikian, istilah "menyalahgunakan kewenangan" seperti halnya "penyalahgunaan wewenang" sebenarnya merupakan istilah yang lahir dalam rumpun Hukum Administrasi Negara, bahkan istilah tersebut merupakan salah satu asas dalam AUPB, yaitu asas tidak menyalahgunakan kewenangan. ${ }^{29}$

Unsur "menyalahgunakan kewenangan" dalam Tipikor dapat ditemukan dalam rumusan Pasal 3 UU Pemberantasan Tipikor, yang selalu dikaitkan dengan jabatan yang dimiliki seseorang pejabat publik (menyalahgunakan kewenangan karena jabatan), yang rumusannya sebagai berikut:

"Setiap orang yang dengan tujuan menguntungkan diri sendiri atau orang lain atau suatu korporasi, menyalahgunakan kewenangan, kesempatan atau sarana yang ada padanya karena jabatan atau kedudukan yang dapat merugikan keuangan negara atau perekonomian negara, dipidana dengan ... rupiah)."

Subjek hukum dalam tindak pidana ini adalah setiap orang yang berarti orang perseorangan atau termasuk korporasi. ${ }^{30}$ Akan tetapi karena korporasi sebagai rechtsperson tidak mungkin memiliki jabatan atau kedudukan seperti natuurlijke person, maka Tipikor yang terdapat dalam ketentuan Pasal 3 tersebut hanya dapat dilakukan oleh orang perseorangan yaitu aparatur Negara atau pejabat publik. ${ }^{31}$

Kewenangan yang dimaksud dalam Pasal 3 UU Pemberantasan Tipikor merupakan kewenangan dari Pegawai Negeri sebagaimana dimaksud dalam ketentuan Pasal 1 angka 2 huruf a, huruf b, huruf c, huruf d, dan huruf e UU Pemberantasan Tipikor, yang pengertiannya lebih luas dari pengertian kewenangan menurut konsep Hukum Tata Negara atau Hukum Tata Usaha

${ }^{29}$ Lihat ketentuan Pasal 10 ayat (1) huruf e UU Administrasi Pemerintahan.

${ }^{30}$ Lihat ketentuan Pasal 1 angka 3 UU Pemberantasan Tipikor.

31 R. Wiyono, Pembahasan Undang-Undang Pemberantasan Tindak Pidana Korupsi, Edisi Kedua, Sinar Grafika, Jakarta, 2012, hlm. 45. Lihat juga Adami Chazawi, Hukum Pidana Materiil dan Formil Korupsi di Indonesia, Bayumedia, Malang, 2005, hlm. 49. Lihat juga Abdul Latif, Hukum Administrasi Dalam..., Op.Cit., hlm. 41. 
Negara yang hanya terbatas pada ketentuan Pasal 1 angka 2 huruf $a$, huruf $b$, huruf c, dan huruf e UU Pemberantasan Tipikor. ${ }^{32}$

Secara yuridis, mengenai menyalahgunakan kewenangan karena jabatan, UU Pemberantasan Tipikor tidak memberikan definisi atau pengertian tersendiri. Istilah "menyalahgunakan kewenangan" justru ditemukan dalam UU Administrasi Pemerintahan yaitu sebagai bagian dari Asas-asas Umum Pemerintahan yang Baik (AUPB), yang diantara berupa "asas tidak menyalahgunakan kewenangan".33

Tabel 1. Bentuk Penyalahgunaan Wewenang dan Asas Tidak Menyalahgunakan Kewenangan

\begin{tabular}{|c|c|}
\hline \multicolumn{2}{|c|}{ UU Administrasi Pemerintahan } \\
\hline $\begin{array}{c}\text { Penyalahgunaan Wewenang } \\
\text { (Pasal 17 s.d. Pasal 18) }\end{array}$ & $\begin{array}{c}\text { Asas Tidak Menyalahgunakan } \\
\text { Kewenangan } \\
\text { (Pasal 10 ayat (1) huruf e) }\end{array}$ \\
\hline $\begin{array}{l}\text { Larangan melampaui Wewenang: } \\
\text { a. Keputusan dan/atau Tindakan yang } \\
\text { dilakukan melampaui masa jabatan } \\
\text { atau batas waktu berlakunya } \\
\text { Wewenang } \\
\text { b. Keputusan dan/atau Tindakan yang } \\
\text { dilakukan melampaui batas wilayah } \\
\text { berlakunya Wewenang kewenangan } \\
\text { c. Keputusan dan/atau Tindakan yang } \\
\text { dilakukan bertentangan dengan } \\
\text { ketentuan peraturan perundang- } \\
\text { undangan }\end{array}$ \\
\hline
\end{tabular}

32 Pegawai Negeri menurut ketentuan Pasal 1 angka 2 UU Pemberantasan Tipikor adalah meliputi: a) pegawai negeri sebagaimana dimaksud dalam Undang-undang tentang Kepegawaian; b) pegawai negeri sebagaimana dimaksud dalam Kitab Undang-undang Hukum Pidana; c) orang yang menerima gaji atau upah dari keuang negara atau daerah; d) orang yang menerima gaji atau upah dari suatu korporasi yang menerima bantuan dari keuangan negara atau daerah; atau e) orang yang menerima gaji atau upah dari korporasi lain yang mempergunakan modal atau fasilitas dari negara atau masyarakat. Lihat R. Wiyono, Pembahasan Undang-Undang Pemberantasan ..., Op.Cit., hlm. 35. Lihat juga Abdul Latif, Hukum Administrasi Dalam..., Op.Cit., hlm. 45. Lihat juga Putusan Mahkamah Agung RI Nomor 2357K/Pid.Sus/2015, tanggal 4 November 2015, hlm. 62-62.

33 Asas tidak menyalahgunakan kewenangan adalah "asas yang mewajibkan setiap Badan dan/atau Pejabat Pemerintahan untuk tidak menggunakan kewenangannya bagi kepentingan pribadi atau kepentingan yang lain dan tidak sesuai dengan tujuan pemberian kewenangan tersebut, tidak melampaui, tidak menyalahgunakan, dan/atau tidak mencampuradukkan kewenangan." Lihat ketentuan Pasal 10 ayat (1) huruf e UU Administrasi Pemerintahan beserta penjelasannya. 


\begin{tabular}{|c|l|}
\hline \multicolumn{2}{|c|}{ UU Administrasi Pemerintahan } \\
\hline $\begin{array}{c}\text { Penyalahgunaan Wewenang } \\
\text { (Pasal 17 s.d. Pasal 18) }\end{array}$ & \multicolumn{1}{|c|}{$\begin{array}{c}\text { Asas Tidak Menyalahgunakan } \\
\text { Kewenangan }\end{array}$} \\
(Pasal 10 ayat (1) huruf e)
\end{tabular}

Sumber: Bahan Hukum Primer, diolah, 2016.

Apabila dicermati, bentuk-bentuk atau jenis perbuatan yang dikategorikan sebagai tindakan menyalahgunakan kewenangan sebagaimana disebutkan dalam penjelasan asas "tidak menyalahgunakan kewenangan", maka bentuk-bentuk atau jenis perbuatan tersebut sama dengan bentuk dan jenis keputusan dan/atau tindakan yang dikategorikan sebagai larangan penyalahgunaan wewenang, bahkan rincian dalam larangan penyalahgunaan wewenang lebih lengkap dan ada yang tidak tercakup dalam penjelasan asas "tidak menyalahgunakan kewenangan". Namun yang pasti dalam penjelasan asas tersebut, unsur penyimpangan tujuan (asas spesialitas) yang dalam Hukum Administrasi Negara selama ini selalu diidentikkan dengan pengertian "penyalahgunaan wewenang", juga dimasukkan dalam penjelasan asas "tidak menyalahgunakan kewenangan".

Larangan bagi Pejabat Administrasi Pemerintahan untuk "tidak menyalahgunakan kewenangan" dalam menetapkan dan/atau melakukan 
keputusan dan/atau tindakan juga terdapat dalam Pasal 8 ayat (3) UU Administrasi Pemerintahan. Sayangnya, dalam undang-undang ini tidak diatur mengenai sanksi apabila terjadi pelanggaran atas ketentuan tersebut.

Adami Chazawi mendefinisikan "menyalahgunakan kewenangan" sebagai perbuatan yang dilakukan oleh orang yang sebenarnya berhak untuk melakukannya, tetapi dilakukan secara salah atau diarahkan pada hal yang salah dan bertentangan dengan hukum atau kebiasaan. Perbuatan "menyalahgunakan kewenangan" hanya mungkin terjadi apabila terpenuhi dua syarat, yaitu: a) si pembuat yang menyalahgunakan kewenangan berdasarkan kedudukan atau jabatan tertentu memang mempunyai kewenangan yang dimaksudkan; b) kedudukan atau jabatan yang mempunyai kewenangan tersebut masih (sedang) dipangku atau dimilikinya. ${ }^{34}$

Badan Pemeriksa Keuangan, mengartikan "menyalahgunakan kewenangan" sebagai perbuatan yang dilakukan dengan cara bertentangan dengan tatalaksana yang semestinya sebagaimana yang diatur dalam peraturan, petunjuk tata kerja, instruksi dinas, dan lain-lain, dan berlawanan atau menyimpang dari maksud tujuan sebenarnya dari pemberian kewenangan, kesempatan atau sarana tersebut. 35

Sementara Indriyanto Seno Adji,36 menyatakan "menyalahgunakan kewenangan" dalam hukum pidana, khususnya dalam Tipikor tidak memiliki pengertian yang eksplisitas sifatnya. Oleh karena itu, dipergunakan pengertian dan kata yang sama yang terdapat atau berasal dari cabang hukum lainnya (Hukum Administrasi Negara) melalui pendekatan ektensif berdasarkan doktrin "De Autonomie van het Materiele Strafrecht" dari H.A. Demeersemen dengan menggunakan pengertian "penyalahgunaan wewenang" dalam Pasal 52 ayat (2) huruf b UU Peradilan TUN, yaitu telah menggunakan wewenangnya untuk tujuan lain dari maksud diberikannya wewenang tersebut atau yang dikenal dengan "detournement de poivoir".

${ }^{34}$ Adami Chazawi, Hukum Pidana ..., Op. Cit., hlm. 66-68.

35 Adami Chazawi, Hukum Pidana ..., Ibid., hlm. 66.

${ }^{36}$ Lihat Putusan MARI Nomor 977K/PID/2004, tanggal 10 Juni 2005, hlm. 196-197. Lihat juga Putusan MARI Nomor 979K/PID/2004, tanggal 10 Juni 2005, hlm. 86-88. 
Pengertian-pengertian "menyalahgunakan kewenangan" yang disampaikan oleh para ahli hukum tersebut (khususnya ahli Hukum Pidana), termasuk pengertian yang disampaikan Badan Pemeriksa Keuangan, ketika dicermati ternyata tidak jauh berbeda dengan pengertian "penyalahgunaan wewenang" yang ada dalam konsep Hukum Administrasi Negara. Pengertian "menyalahgunakan kewenangan" ditekankan pada penyimpangan tujuan dari pemberian kewenangan tersebut (penyimpangan asas spesialitas), walapun pada beberapa pengertian ditambahkan dengan unsur lain seperti penyalahgunaan prosedur dan perbuatan yang dilakukan tanpa wewenang/kewenangan. Tetapi unsur penyimpangan tujuan yang selama ini identik dengan pengertian "penyalahgunaan wewenang" dalam Hukum Administrasi Negara selalu disematkan terhadap pengertian "menyalahgunakan kewenangan".

Absorbsi pengertian "penyalahgunaan wewenang" kedalam pengertian "menyalahgunakan kewenangan" selain dalam ranah akademis, juga dilakukan dalam tataran praktis. Praktik peradilan pidana, khususnya Peradilan Tipikor melalui pendekatan ekstensif dengan menggunakan doktrin otonomi hukum pidana telah menggunakan pengertian "penyalahgunaan wewenang" dalam Hukum Administrasi Negara untuk menjelaskan unsur "menyalahgunakan kewenangan" dalam Tipikor dan telah menjadi yurisprudensi.

Doktrin otonomi hukum pidana pertama kali diterima oleh Pengadilan Negeri Jakarta Utara dan dikuatkan oleh Mahkamah Agung RI melalui Putusan Nomor: 1340K/Pid/1992, tanggal 17 Februari 1992, dalam perkara Tipikor yang dikenal dengan perkara "Sertifikat Ekspor", dimana Kabid Ekspor Kanwil IV, Ditjen Bea Cukai Tanjung Priok, Jakarta didakwa melanggar Pasal 1 ayat (1) sub b UU No. 3 Tahun 1971 tentang Pemberantasan Tipikor. ${ }^{37}$ Melalui putusan tersebut Mahkamah Agung RI melakukan penghalusan hukum (rechtsvervijning) terhadap pengertian "menyalahgunakan kewenangan" dalam pasal tersebut, dengan cara

${ }^{37}$ Pasal 1 ayat (1) sub b Undang-Undang Nomor 3 Tahun 1971, selengkapnya berbunyi "Dihukum karena tindak pidana korupsi ialah barang siapa dengan tujuan menguntungkan diri sendiri atau orang lain atau suatu Badan, menyalahgunakan kewenangan, kesempatan atau sarana yang ada padanya karena jabatan atau kedudukan, yang secara langsung atau tidak langsung dapat merugikan keuangan negara atau perekonomian negara”. 
mengambil alih pengertian "penyalahgunaan wewenang" yang ada dalam UU Peradilan TUN (Pasal 53 ayat (2) huruf b). 38

Putusan tersebut kemudian menjadi yurisprudensi dan dijadikan rujukan oleh Hakim Peradilan Pidana dalam pemeriksaan dan pembuktian unsur "menyalahgunakan kewenangan" dalam Tipikor, bahkan setelah Pasal 53 ayat (2) huruf $\mathrm{b}$ dirubah dan tidak lagi dicantumkan dalam perubahan pertama UU Peradilan TUN. ${ }^{39}$ Misalnya saja dalam Putusan Mahkamah Agung RI Nomor: 1485K/Pid.Sus/2013, tanggal 2 Oktober 2013, dengan terdakwa M. Riza Kurniawan, S.E. bin Sutikno. ${ }^{40}$

Pendekatan ekstensif melalui Doktrin Otonomi Hukum Pidana dalam memberikan pengertian unsur "menyalahgunakan kewenangan" dalam pembuktian Tipikor juga masih digunakan setelah lahirnya UU Administrasi Pemerintahan, yaitu dalam Putusan Hakim Pengadilan Tanjung Pinang Nomor: 3/Pid.Sus-TPK/2015/PN.Tpg, tanggal 11 Juni 2015, ketika memutus terdakwa korupsi Yusrizal, A.Ptnh. bin Muhammad Yusuf Bhawan. ${ }^{41}$

Absorbsi pengertian "penyalahgunaan wewenang" kedalam pengertian "menyalahgunakan kewenangan" juga dapat dilihat dalam kesimpulan penelitian disertasi yang di lakukan oleh Budi Parmono dengan judul "Penyalahgunaan Wewenang Dalam Tindak Pidana Korupsi di Indonesia", dimana pada bagian kesimpulan pertama huruf c dinyatakan:

“... sebenarnya kriteria penyalahgunaan wewenang yang berkembang dalam Hukum Administrasi Negara diadopsi kriteria bagian inti delik penyalahgunaan wewenang dalam tindak pidana korupsi melalui doktrin otonomi hukum pidana yang meliputi (1) tindakan-tindakan pejabat tersebut adalah benar ditujukan untuk kepentingan umum, tetapi telah menyimpang dari tujuan apa kewenangan tersebut diberikan oleh undang-undang atau peraturan yang lain; (2) kecermatan; dan (3) kepatutan.42

\footnotetext{
${ }^{38}$ Lihat Putusan MARI Nomor 977K/PID/2004, tanggal 10 Juni 2005, hlm. 196-197. Lihat juga Putusan MARI Nomor 979K/PID/2004, tanggal 10 Juni 2005, hlm. 86-88.

${ }^{39}$ Perubahan pertama UU Peradilan TUN dilakukan melalui UU Nomor 9 Tahun 2004, yang diundangkan pada tanggal 29 Maret 2004.

${ }^{40}$ Lihat Putusan Mahkamah Agung RI Nomor 1485K/Pid.Sus/2013, tanggal 2 Oktober 2013, hlm. 129-132.

${ }^{41}$ Lihat Putusan Hakim Pengadilan Tanjung Pinang Nomor 3/Pid.Sus-TPK/2015/PN.Tpg, tanggal 11 Juni 2015, hlm. 94-95. Substansi serupa juga dapat ditemukan dalam Putusan Hakim Pengadilan Tanjung Pinang Nomor 2/Pid.Sus-TPK/2015/PN.Tpg, tanggal 11 Juni 2015, hlm. 105-106, Putusan Nomor 2/Pid.SusTPK/2015/PN.Tpg oleh Mahkamah Agung RI juga dinyatakan sebagai yurisprudensi, namun belum memiliki kekuatan hukum tetap karena masih dilakukan upaya hukum.

${ }^{42}$ Budi Parmono, Penyalahgunaan Wewenang ..., Op. Cit., hlm. 382.
} 
Bahkan dalam disertasinya tersebut, Budi Darmono tidak menggunakan istilah "menyalahgunakan kewenangan" untuk menyebut unsur Tipikor, tetapi menggunakan istilah "penyalahgunaan wewenang".

Berdasarkan uraian tersebut di atas bisa disimpulkan bahwa secara teoritis dan praktis, konsep "menyalahgunakan kewenangan" dengan konsep "penyalahgunaan wewenang" merupakan hal yang sama, sehingga unsur "menyalahgunakan kewenangan" dalam Tipikor selain berada dalam kewenangan absolut Peradilan Tipikor, juga merupakan kewenangan absolut Peradilan Administrasi. Kewenangan absolut Peradilan Tipikor secara atributif diberikan UU Pengadilan Tipikor yang lebih dahulu diundangkan (pada tanggal 29 Oktober 2009) sebagaimana dinyatakan dalam Pasal 5 dan Pasal 6 undang-undang dimaksud jo. Pasal 3 UU Pemberantasan Tipikor dan sudah berjalan dalam praktik peradilan pidana, khususnya Tipikor.

Sementara itu, kewenangan absolut Peradilan Administrasi secara atributif diberikan oleh UU Administrasi Pemerintahan dengan mengacu pada ketentuan Pasal 21 ayat (1) jo. Pasal 1 angka 18 Jo. Pasal 17 undang-undang tersebut. UU Administrasi Pemerintahan yang diundangkan kemudian (pada 17 Oktober 2014), secara hierarki memiliki kedudukan yang setara dengan UU Pengadilan Tipikor dan secara substansi mengatur aspek yang sama, namun UU Administrasi Pemerintahan tidak menyinggung apalagi mencabut kewenangan absolut Peradilan Tipikor dalam memeriksa unsur menyalahgunakan kewenangan dalam Tipikor. Padahal, kedua undang-undang tersebut dibentuk dalam rangka pemberantasan Tipikor. ${ }^{43}$

\section{Unsur Menyalahgunakan Kewenangan dalam Tipikor sebagai Kompetensi Absolut Peradilan Administrasi}

Secara teori, ketika terjadi antinomi hukum karena adanya conflict of norm, maka dapat diselesaikan dengan asas preferensi hukum, yang terdiri dari 3 (tiga)

43 UU Pengadilan Tipikor dibentuk dalam rangka peningkatan kapasitas kelembagaan serta peningkatan penegakan hukum sebagai upaya pencegahan dan pemberantasan tindak pidana korupsi (Lihat alinea pertama Penjelasan UU Pengadilan Tipikor). Sedangakan UU Administrasi Pemerintahan merupakan dasar hukum dalam penyelenggaraan pemerintahan di dalam upaya meningkatkan good governance sebagai upaya untuk mencegah praktik korupsi, kolusi, dan nepotisme (Lihat alinea sepuluh Penjelasan UU Administrasi Pemerintahan. Lihat juga Naskah Akademik UU Administrasi Pemerintahan, hlm. 26). 
asas, yaitu: lex superior derogat legi inferiori; lex specialis derogat legi generalis; dan lex posteriori derogate legi priori. ${ }^{44}$ Asas hukum lex superior derogat legi inferiori, dapat diterapkan ketika terjadi pertentangan antara peraturan perundang-undangan yang secara hierarki tingkatannya lebih rendah dengan peraturan perundangundangan di atasnya yang lebih tinggi. Menurut asas ini peraturan perundangundangan dengan tingkatan lebih rendah, keberlakuannya dikesampingkan oleh peraturan perundang-undangan yang tingkatannya lebih tinggi, kecuali substansi yang diatur oleh peraturan perundang-undangan lebih tinggi oleh undang-undang ditetapkan sebagai wewenang peraturan perundang-undangan tingkat lebih rendah.

Berikutnya, asas hukum lex specialis derogat legi generalis, asas ini dapat diaplikasikan ketika terjadi pertentangan antara peraturan perundang-undangan yang bersifat khusus dengan peraturan perundang-undangan yang bersifat umum. Berdasarkan asas ini, aturan hukum yang umum dapat dikesampingkan oleh aturan hukum yang khusus ketika memenuhi beberapa prinsip yaitu: a) aturanaturan hukum tersebut harus berada dalam lingkungan hukum (rezim) yang sama, misalnya UU Pemberantasan Tipikor dengan KUHP yang sama-sama termasuk rumpun hukum pidana; $b$ ) aturan-aturan hukum tersebut levelnya harus sederajat (undang-undang dengan undang-undang); dan $c$ ) ketentuan-ketentuan lain yang terdapat dalam aturan hukum umum tetap berlaku, kecuali yang diatur khusus dalam aturan hukum khusus tersebut.

Terakhir, asas hukum "lex posteriori derogate legi priori", yang dapat diimplementasikan ketika terjadi pertentangan antara hukum yang dibuat terdahulu dengan hukum yang dibentuk kemudian. Keberlakuan asas ini harus di dasarkan pada terpenuhinya beberapa prinsip berikut: $a$ ) aturan hukum yang baru levelnya harus sederajat atau lebih tinggi dari aturan hukum yang lama; dan $b$ ) aspek yang diatur dalam hukum baru dan hukum lama sama.

Apabila melihat penjelasan dari masing-masing asas tersebut, maka asas preferensi hukum yang dapat diterapkan terhadap conflict of norm dalam ketentuan UU Pengadilan Tipikor jo. UU Pemberantasan Tipikor dengan ketentuan dalam

\footnotetext{
${ }^{44}$ Wasis Susetio, "Disharmoni Peraturan Perundang-Undangan di Bidang Agraria", Artikel dalam Jurnal Lex Jurnalica, Volume 10 Nomor 3, Desember 2013, hlm. 145.
} 
UU Administrasi Pemerintahan adalah asas hukum "lex posteriori derogate legi priori", karena pertentangan terjadi antara norma yang termuat dalam undangundang yang telah ada sebelumnya, dengan ketentuan yang terdapat dalam undang-undang yang baru dibentuk. ${ }^{45}$ Selain itu, ketiga undang-undang tersebut kedudukannya dalam hierarki perundang-undangan setara yaitu selevel undangundang dan substansi norma yang dipertentangkan aspeknya sama, yaitu mengenai penanganan masalah penyalahgunaan wewenang/menyalahgunakan kewenangan.

Ketika ditelusuri ratio legis pembentukan ketiga peraturan perundangundangan tersebut, terdapat keterkaitan yang sangat erat antara ketiganya, yaitu sama-sama dibentuk dalam rangka upaya pemberantasan Tipikor. UU Pengadilan Tipikor jo. UU Pemberantasan Tipikor yang berada dalam rumpun Hukum Pidana diniatkan untuk memberantas Tipikor melalui sarana penindakan (tindakan represif), sedangkan UU Administrasi Pemerintahan, walaupun berada dalam rumpun Hukum Administrasi Negara dimaksudkan sebagai sarana pemberantasan Tipikor melalui tindakan pencegahan (preventif) dengan pendekatan reformasi birokrasi. Benang merahnya dapat dilihat juga dalam substansi pengaturan penyelenggaraan Negara oleh Undang-Undang Nomor 28 Tahun 1999 tentang Penyelenggara Negara Yang Bersih dan Bebas Dari Korupsi, Kolusi dan Nepotisme, yang di dalamnya kental mengatur hubungan antara HAN dan hukum pidana (korupsi). ${ }^{46}$

Berdasarkan asas hukum "lex posteriori derogate legi priori" ini, maka kewenangan untuk memeriksa dan memutus penyalahgunaan kewenangan dalam Tipikor merupakan kompetensi absolut Peradilan Administrasi, karena kompetensi absolut yang dimiliki Peradilan Administrasi diberikan oleh UU Administrasi Pemerintahan yang dibentuk kemudian (post) setelah lahirnya UU Pemberantasan Tipikor dan UU Peradilan Tipikor yang telah ada lebih dulu (prior). ${ }^{47}$

45 Sidharta, "Penemuan Hukum Melalui Putusan Hakim", Makalah, disampaikan dalam Seminar Nasional Pemerkuatan Pemahaman Hak Asasi Manusia Untuk Hakim Seluruh Indonesia, yang diselenggarakan oleh Komisi Yudisial RI, PUSHAM UII, dan Norsk Senter For Menneskerettigheter Norwegian Centre For Human Rights, Hotel Grand Angkasa Medan, tanggal 2-5 Mei 2011, hlm 10.

46 Yulius, "Perkembangan Pemikiran ..., Op.Cit.., hlm. 375.

47 UU Pengadilan Tipikor diundangkan pada tanggal 29 Oktober 2009, sedangkan UU Administrasi Pemerintahan diundangkan pada tanggal 17 Oktober 2014. 
Selain itu, apabila merujuk pada arah politik hukum pemerintah dalam upaya pemberantasan korupsi, terjadi pergeseran politik hukum pemerintah dalam upaya pemberantasan Tipikor yang dilakukan oleh penyelenggara Negara. Saat ini, pemerintah cenderung melakukan penyeimbangan antara upaya pencegahan (prefentif) dengan upaya penindakan (represif). Romli Atmasasmita, ${ }^{48}$ menyatakan terdapat perubahan arah politik hukum terkait penegakan hukum dalam pemberantasan korupsi di Indonesia, dimana upaya pencegahan korupsi didudukkan sama pentingnya dengan penindakan korupsi. Oleh karena itu, pendekatan yang selama ini digunakan dalam UU Pemberantasan Tipikor, yang menjadikan tindakan represif sebagai "primum remedium" harus ditinjau ulang. Hukum pidana harus dikembalikan kepada khittahnya sebagai senjata pamungkas atau sebagai upaya terakhir yang harus dipergunakan dalam upaya penegakan hukum sesuai dengan asas "ultimum remedium". ${ }^{49}$

Apalagi dalam konteks Hukum Administrasi, keberadaan sanksi pidana menurut Barda Nawawi Arief,50 pada hakikatnya merupakan perwujudan dari kebijakan menggunakan hukum pidana sebagai sarana untuk menegakkan/ melaksanakan hukum administrasi atau dengan kata lain merupakan bentuk "fungsionalisasi/operasionalisasi/instrumentaliasi hukum pidana di bidang hukum administrasi", sehingga berada pada tahapan terakhir. Hal ini seperti yang dikemukakan oleh W.F Prins yang dikutip Philipus M. Hadjon, ${ }^{51}$ bahwa hampir setiap peraturan berdasarkan hukum administrasi diakhiri dengan ketentuan pidana sebagai "in cauda venenum" (secara harfiah berarti: ada racun di ekor/buntut).

48 Romli Atmasasmita, "Penyalahgunaan Wewenang Oleh Penyelenggara Negara: Suatu Catatan Kristis Atas UU RI Nomor 30 Tahun 2014 tentang Administrasi Pemerintaban Dibubungkan Dengan UU RI Nomor 20 Tahun 2001 tentang Perubahan Atas UU RI Nomor 31 Tahun 1999 tentang Pemberantasan Tindak Pidana Korupsi”, Makalah, disampaikan dalam Seminar Nasional dalam rangka H.U.T. IKAHI Ke-62 dengan tema "Undang-Undang Administrasi Pemerintahan, Menguatkan atau Melemahkan Upaya Pemberantasan Korupsi”, Hotel Mercure, Jakarta, tanggal 26 Maret 2015, hlm. 6-7.

${ }^{49}$ Suhariyono AR, “Perumusan Sanksi Pidana Dalam Pembentukan Peraturan Perundang-Undangan”, Artikel dalam Jurnal Perspektif, Volume XVII No. 1 Tahun 2012 Edisi Januari, hlm. 21.

${ }^{50}$ Barda Nawawi Arief, Beberapa Aspek Kebijakan Penegakan dan Pengembangan Hukum Pidana, PT. Citra Aditya, Bandung, 2005, hlm. 139.

51 Philipus, M. Hadjon, dkk., Pengantar Hukum Administrasi Indonesia, Gadjah Mada University Press, Yogyakarta, 2005, hlm. 245. 


\section{Penutup}

Berdasarkan kajian atas permasalahan di atas, dapat disimpulkan bahwa kewenangan untuk memeriksa dan memutus unsur "menyalahgunakan kewenangan" karena jabatan dalam Tipikor merupakan kompetensi absolut Peradilan Administrasi, karena konsep "penyalahgunaan wewenang" dalam UU Administrasi Pemerintahan dan konsep "menyalahgunakan kewenangan" dalam UU Pemberantasan Tipikor secara teoritis dan praktis merupakan konsep yang sama. Ketika ada dua hukum (kebijakan legislasi) dengan level sederajat mengatur aspek yang sama, maka berdasarkan asas "lex posteriori derogate legi priori", hukum yang dibentuk kemudian yang berlaku.

Akar permasalahan timbulnya potensi sengketa kewenangan mengadili antara Peradilan Tipikor dengan Peradilan Administrasi dalam penanganan penyalahgunaan kewenangan dalam Tipikor karena adanya pembedaan konsep, teori, dan pengaturan tentang "wewenang" dan "kewenangan" dalam hukum Indonesia. Sementara itu, secara terminologi kedua kata tersebut berasal dari kata yang sama yaitu "wenang" dengan makna yang tidak jauh berbeda, karena keduanya selalu dikonotasikan dengan "hak dan kekuasaan" pejabat publik. Agar tidak terjadi kerancuan pemahaman dan pengaturan mengenai "wewenang" dan "kewenangan", para akademisi hukum, legislatif, dan penegak hukum kiranya perlu melakukan penegasan dan penyamaan persepsi mengenai istilah yang akan digunakan dalam hukum Indonesia dengan memilih salah satu istilah tersebut.

\section{Daftar Pustaka}

\section{Buku}

Arief, Barda Nawawi, Beberapa Aspek Kebijakan Penegakan dan Pengembangan Hukum Pidana, PT. Citra Aditya, Bandung, 2005.

Bull, Victoria, Oxford Learner's Pocket Dictionary: Fourth Edition, Oxford University Press, Oxford, 2012.

Chazawi, Adami, Hukum Pidana Materiil dan Formil Korupsi di Indonesia, Bayumedia, Malang, 2005.

Hadjon, Philipus M., dkk., Pengantar Hukum Administrasi Indonesia, Gadjah Mada University Press, Yogyakarta, 2005. 
dkk., Hukum Administrasi dan Tindak Pidana Korupsi: Cetakan Kedua, Gajahmada University Press, Yogyakarta, 2012.

Latif, Abdul, Hukum Administrasi Dalam Tindak Pidana Korupsi, Prenada Media Group, Jakarta, 2014.

Moeimam, Susi dan Steinhauer, Hein, Kamus Belanda-Indonesia, Gramedia Pustaka, Jakarta, 2005.

Parmono, Budi, Penyalahgunaan Wewenang Dalam Tindak Pidana Korupsi di Indonesia: Disertasi, Fakultas Hukum UB, Malang, 2011.

Permana, Tri Cahya Indra, Hak Permohonan Pejabat/Badan Atas Dugaan Penyalahgunaan Wewenang: Bunga Rampai Peradilan Administrasi Kontemporer, Editor Subur, dkk., Genta Press, Yogyakarta, 2014.

Pimpinan Pusat Ikatan Hakim Indonesia (PP IKAHI), Undang-Undang Administrasi Pemerintahan Dalam Upaya Pemberantasan Korupsi, Sinar Grafika, Jakarta Timur, 2016.

Wiyono, R., Pembahasan Undang-Undang Pemberantasan Tindak Pidana Korupsi, Edisi Kedua, Sinar Grafika, Jakarta, 2012.

\section{Jurnal dan Makalah}

Atmasasmita, Romli, "Penyalahgunaan Wewenang Oleh Penyelenggara Negara: Suatu Catatan Kristis Atas UU RI Nomor 30 Tahun 2014 tentang Administrasi Pemerintahan Dihubungkan Dengan UU RI Nomor 20 Tahun 2001 tentang Perubahan Atas UU RI Nomor 31 Tahun 1999 tentang Pemberantasan Tindak Pidana Korupsi", Makalah, disampaikan dalam Seminar Nasional dalam rangka H.U.T. IKAHI Ke-62 dengan tema "Undang-Undang Administrasi Pemerintahan, Menguatkan atau Melemahkan Upaya Pemberantasan Korupsi", Hotel Mercure, Ancol Jakarta, tanggal 26 Maret 2015.

Hadjon, Philipus M., "Peradilan Tata Usaha Negara Dalam Konteks Undang-Undang Nomer 30 Th. 2014", Makalah, disampaikan dalam Colloqium Membedah Undang-Undang Nomor 30 Tahun 2014 tentang Administrasi Pemerintahan, 5 Juni 2015, Garden Palace Surabaya.

"Peradilan Tata Usaha Negara Dalam Konteks Undang-Undang No. 30 Th. 2014 tentang Administrasi Pemerintahan", Artikel dalam Jurnal Hukum dan Peradilan, Badan Penelitian dan Pengembangan Hukum dan Peradilan Mahkamah Agung RI, Volume 04 Nomor 1 Maret 2015.

Muhlizi, Arfan Faiz, "Reformulasi Diskresi Dalam Penataan Hukum Administrasi", Artikel dalam Jurnal RechtsVinding, Volume 1 Nomor 1 Januari-April 2012.

Nirwanto, D. Andhi, "Arah Pemberantasan Korupsi Ke Depan (Pasca Undang-Undang Administrasi Pemerintahan)", Makalah, disampaikan dalam Seminar Nasional dalam rangka H.U.T. IKAHI Ke-62 dengan tema "UndangUndang Administrasi Pemerintahan, Menguatkan atau Melemahkan 
Upaya Pemberantasan Korupsi", Hotel Mercure, Jakarta, tanggal 26 Maret 2015.

Sidharta, "Penemuan Hukum Melalui Putusan Hakim", Makalah, disampaikan dalam Seminar Nasional Pemerkuatan Pemahaman Hak Asasi Manusia Untuk Hakim Seluruh Indonesia, yang diselenggarakan oleh Komisi Yudisial RI, PUSHAM UII, dan Norsk Senter For Menneskerettigheter Norwegian Centre For Human Rights, Hotel Grand Angkasa Medan, tanggal 2-5 Mei 2011.

Suhariyono AR., "Perumusan Sanksi Pidana Dalam Pembentukan Peraturan PerundangUndangan", Artikel dalam Jurnal Perspektif, Volume XVII No. 1 Tahun 2012 Edisi Januari.

Susetio, Wasis, "Disharmoni Peraturan Perundang-Undangan Di Bidang Agraria", Artikel dalam Jurnal Lex Jurnalica, Volume 10 Nomor 3, Desember 2013.

Yulius, "Perkembangan Pemikiran dan Pengaturan Penyalahgunaan Wewenang di Indonesia (Tinjauan Singkat Dari Perspektif Hukum Administrasi Negara Pasca Berlakunya Undang-Undang Nomor 30 Tahun 2014)", Artikel dalam Jurnal Hukum dan Peradilan, Badan Penelitian dan Pengembangan Hukum dan Peradilan Mahkamah Agung RI, Volume 04 Nomor 3 November 2015.

\section{Peraturan Perundang-undangan}

Undang-Undang Republik Indonesia Nomor 3 Tahun 1971 tentang Pemberantasan Tindak Pidana Korupsi.

Undang-Undang Republik Indonesia Nomor 5 Tahun 1986 tentang Peradilan Tata Usaha Negara, sebagaimana telah beberapa kali diubah terakhir dengan Undang-Undang Republik Indonesia Nomor 51 Tahun 2009.

Undang-Undang Republik Indonesia Nomor 31 Tahun 1999 tentang Pemberantasan Tindak Pidana Korupsi, sebagaimana telah diubah dengan Undang-Undang Republik Indonesia Nomor 20 Tahun 2001.

Undang-Undang Republik Indonesia Nomor 46 Tahun 2009 tentang Pengadilan Tindak Pidana Korupsi.

Undang-Undang Republik Indonesia Nomor 30 Tahun 2014 tentang Administrasi Pemerintahan.

Instruksi Presiden RI Nomor 1 Tahun 2016 tentang Percepatan Pelaksanaan Proyek Strategis Nasional.

\section{Putusan Pengadilan}

Putusan Mahkamah Agung Republik Indonesia (MARI) Nomor 977K/PID/2004, tanggal 10 Juni 2005.

Putusan MARI Nomor 979K/PID/2004, tanggal 10 Juni 2005.

Putusan MARI Nomor 14/Pid.Sus /2012/PN.AB, tanggal 4 September 2012.

Putusan MARI Nomor 03/PID.SUS/TIPIKOR/2013/PN.PBR., tanggal 1 Mei 2013. 
Putusan Mahkamah Agung RI Nomor 1485K/Pid.Sus/2013, tanggal 2 Oktober 2013.

Putusan Mahkamah Agung RI Nomor 2357K/Pid.Sus/2015, tanggal 4 November 2015.

Putusan Hakim Pengadilan Tanjung Pinang Nomor 2/Pid.Sus-TPK/2015/PN.Tpg, tanggal 11 Juni 2015.

Putusan Hakim Pengadilan Tanjung Pinang Nomor 3/Pid.Sus-TPK/2015/PN.Tpg, tanggal 11 Juni 2015.

\section{Internet}

Badan Pengembangan dan Pembinaan Bahasa Kementerian Pendidikan dan Kebudayaan (BP2B, Kemendikbud), Kamus Besar Bahasa Indonesia (KKBI), Kamus Versi Online/Daring (Dalam Jaringan), kbbi.web.id/salah\%20guna. menyalahgunakan, diunduh pada hari Rabu, 8 Maret 2016.

BP2B, Kemendikbud, KKBI, Daring, kbbi.web.id/wenang, diakses tanggal 6 Desember 2015.

http: / / www.hukumonline.com/berita/baca/lt5514fdcf7f91b/uu-administrasipemerintahan-trigger-berantas-korupsi, diakses tanggal 28 Februari 2016.

http: / / news.detik.com/berita/2873765/uu-administrasi-pemerintahan-dinilaimengudeta-pem-berantasan-korupsi, diakses tanggal 28 Februari 2016. 